\title{
Pengaruh Aplikasi Blower dan Tipe Pengemasan Terhadap Mutu Cabai Rawit Segar (Capsicum frutescens linn) Selama Transportasi
}

\author{
Effect of Blower Application and Types of Packaging on The Quality of Fresh Chili Pepper \\ (Capsicum frutescens linn) During Transportation \\ Musthofa Lutfi ${ }^{*}$, Joko Prasetyo, Irma Putri Pujianti, Dewi Maya Maharani \\ Jurusan Keteknikan Pertanian - Fakultas Teknologi Pertanian - Universitas Brawijaya \\ Jl. Veteran, Malang 65145 \\ *Email: lutfi@ub.ac.id
}

Diterima: 29 Januari 2019; Disetujui: 24 Juli 2019

\begin{abstract}
ABSTRAK
Cabai rawit adalah salah satu produk hortikultura yang memiliki nilai ekonomis tinggi namun mudah mengalami kerusakan/layu selama proses pengemasan dan tranportasi. Tujuan penelitian ini adalah untuk mengetahui pengaruh aplikasi blower dan tipe pengemasan yang paling aman selama proses transportasi terhadap mutu cabai rawit segar berdasarkan perubahan suhu, kerusakan mekanis, susut bobot, kadar air, dan kekerasan cabai. Metode penelitian eksperimental yang digunakan adalah RAL (Rancangan Acak Lengkap) dengan 2 perlakuan. Perlakuan pertama dalam 2 taraf, yaitu dengan blower dan tanpa blower. Sedang perlakuan kedua adalah tipe pengemasan dalam 3 taraf, yaitu kemasan karung, keranjang, dan kardus. Tiap sampel diisi cabai rawit sebanya $4 \mathrm{~kg}$. Dari kombinasi kedua perlakuan tersebut diperoleh 5 perlakuan dengan 3 kali ulangan. Data yang diperoleh dari penelitian ini dianalisis dengan Analisis Varians dan dilanjutkan dengan Uji BNT (Beda Nyata Terkecil) 5\%. Hasil penelitian menunjukkan bahwa aplikasi blower dan tipe pengemasan menunjukkan perbedaan yang tidak nyata $(P<0.05)$ terhadap kerusakan mekanis dan kadar air cabai rawit segar, tetapi aplikasi blower dan tipe pengemasan menunjukkan perbedaan yang nyata $(P>0.05)$ terhadap susut bobot dan kekerasan. Kesimpulan dari penelitian ini adalah penggunaan blower dan jenis pengemasan kardus merupakan kombinasi perlakuan yang paling aman selama simulasi transporasi dengan rata-rata nilai kerusakan mekanis $1.27 \%$, susut bobot $0.54 \%$, kadar air $0.76 \%$, dan kekerasan $1.57 \mathrm{kgf} / \mathrm{cm}^{2}$.
\end{abstract}

Kata kunci: blower; cabai rawit; kerusakan mekanis; pengemasan; transportasi

\section{ABSTRACT}

Chili Pepper is one of the horticultural products that has high economic value but is easily damaged / wilted during the packaging and transportation process. The purpose of this study was to determine the effect of applying a blower and types of packaging during the transportation process on the quality of fresh Chili Pepper based on temperature changes, mechanical damage, weight loss, moisture content, and hardness. The experimental design of this study was CRD (Complete Random Design) 2 factors. The first factor is the blower (with a blower, without a blower). The second factor is the type of packaging (packaging sacks, baskets, and cardboard). In each sample filled with $4 \mathrm{~kg}$ of Chili Pepper, by combining the two treatments. Of these 6 treatments were obtained with 3 replications. Data obtained from this study were analyzed by Variance Analysis and continued with the smallest range of LSD (Least Significance Different) $5 \%$. The results showed that the addition of blowers and types of packaging (sacks, baskets, and cardboard) showed no significant difference $(P<0.05)$ on mechanical damage and fresh chili water content, but gave a significant difference $(P>0.05)$ to shrinkage weight and hardness with the addition of blowers and types of packaging (sacks, baskets and cardboard). The conclusion of this study is the use of blower and type of cardboard packaging is the safest combination of treatments during the simulation with an average mechanical damage value of $1.27 \%$, weight loss of $0.54 \%$, water content of $0.76 \%$, and hardness of $1.57 \mathrm{kgf} / \mathrm{cm}^{2}$.

Keywords: blower; chili pepper; mechanical damage; packaging; transportation

\section{PENDAHULUAN}

Cabai adalah salah satu komoditi produk hortikultura yang memiliki nilai jual tinggi dan banyak dibudidayakan oleh para petani di Indonesia. Cabai di Indonesia terdiri dari beberapa macam spesies, salah satunya yaitu cabai rawit (Capsicum frutescens linn). Cabai rawit mudah mengalami perubahan tekstur lembek/busuk/rusak, namun produsen maupun konsumen menginginkan dalam bentuk segar sehingga pengemasan dan transportasi menjadi titik kritis pascapanen untuk menjaga kesegaran produk saat didistribusikan hingga sampai ke konsumen.
Pengemasan merupakan kegiatan untuk melindungi kesegaran produk pertanian saat pengangkutan, pendistribusian dan atau penyimpanan agar mutu produk tetap terpelihara (Sembiring, 2009). Sedangkan menurut Maezawa (1990), kemasan distribusi dirancang dan dipilih terutama untuk mengatasi faktor getaran (vibrasi) dan kejutan (shock) karena faktor ini sangat berpengaruh terhadap besar kecilnya kerusakan yang terjadi.

Transportasi/pengangkutan merupakan mata rantai penting dalam penanganan pascapanen dan distribusi cabai. Selama pengangkutan, cabai dapat mengalami kerusakan mekanis karena kontak dengan wadah atau 
dengan cabai yang lain akibat goncangan. Kerusakan fisiologis juga bisa terjadi akibat gangguan metabolisme dalam bahan. Proses respirasi yang masih berlangsung dalam cabai yang ditumpuk menghasilkan $\mathrm{H}_{2} \mathrm{O}, \mathrm{CO}_{2}$, dan energi dalam bentuk panas. Jika panas yang dihasilkan berlebihan akan mengakibatkan cabai menjadi layu, respirasi makin cepat, dan jaringan sel mati (Taufik, 2011).

Untuk mengatasi permasalahan tersebut, blower merupakan aternatif solusi. Pada penelitian ini blower diaplikasikan pada alat simulasi transportasi. Exhaust fan motor ditambahkan pada alat simulasi yang bertujuan untuk mencegahpanas di dalam kemasan selama transportasi. Menurut Raharjo (2016) blower atau fan merupakan sebuah alat penyedia energi mekanik dari sebuah impeller yang berputar untuk menghasilkan gerakan udara atau embusan udara sebagai tenaga penggerak kipas angin (blower). Tujuan dari penelitian ini adalah untuk mempertahankan mutu, memberikan produk segar untuk konsumen, dan menghindari kerusakan/layu pada cabai rawit segar, maka diperlukan variasi perlakuan pasca panen diantaranya pengaplikasian blower dan tipe pengemasan.

\section{BAHAN DAN METODE}

\section{Alat dan Bahan}

Bahan yang digunakan dalam penelitian ini adalah cabai rawit segar (Capsicum frutescens linn) varietas Camelia. Alat yang digunakan dalam dalam penelitian ini antara lain alat meja getar, blower, karung, keranjang, kardus, pipa PVC, stop contact, gergaji, bor listrik, tachometer, stopwatch, timbangan digital, desikator, oven, sarung tangan, cawan, cone penetrometer, termometer, gunting, pisau, lakban, tali rafia, dan software solidwork.

\section{Metode Penelitian}

Metode yang dilakukan pada penelitian yaitu:

1. Pertama cabai rawit segar yang telah didapatkan akan dibersihkan terlebih dahulu, dipisahkan dari kotoran kemudian disortasi. Pensortasian dilakukan untuk menyeragamkan kualitas cabai rawit segar yang didapatkan.

2. Sampel cabai diambil untuk melakukan pengukuran kadar air dan kekerasan sebagai kontrol sebelum simulasi transportasi. Cabai dimasukkan ke dalam setiap kemasan (karung, keranjang, kardus tanpa blower dan karung, keranjang, kardus dengan penambahan blower). Pengisian ke setiap pengemasan karung masing-masing $4 \mathrm{~kg}$ dipastikan dilakukan dengan benar/tidak ada yang rusak. Sesuai rancangan percobaan ada variasi 6 sampel pada penelitian ini. Kemasan ditutup menggunakan rafia agar pada saat simulasi cabai tidak tercecer keluar.

3. Diukur suhu sebelum dilakukan simulasi pada masingmasing karung.

4. Setiap kemasan ditimbang untuk mengetahui berat awal dari cabai yang telah dikemas. Kemasan diletakkan di atas meja simulator dengan 3 tumpukan. Hal ini dilakukan sesuai dengan SNI 01-4480-1998 cabai merah segar perihal tumpukan pada saat transportasi yaitu 2-3 tumpukan.

5. Tachometer disiapkan, alat dinyalakan, sekrup disesuaikan untuk perlakuan simulasi transportasi dengan frekuensi 3.3 Hz (198 rpm).

6. Ditunggu selama 3 jam atau 180 menit untuk tiap perlakuan dengan metode RAL (Rancangan Acak Lengkap).
7. Setelah dilakukan simulasi getar, tiap pengemasan diamati dan diuji karakteristik seperti ditimbang, diukur suhu, disortasi cabe rusak (kerusakan mekanis) kemudian diambil sampel untuk uji kekerasan dan kadar air (masing-masing perlakuan diambil sebanyak 3 sampel cabai rawit segar).

8. Dicatat hasil. Selesai.

\section{Simulasi Transportasi dengan Frekuensi Getaran Pegas $3.3 \mathrm{~Hz}$}

Simulasi transportasi dengan frekuensi $3.3 \mathrm{~Hz}$ pada Tabel 1 diketahui nilai amplitudo rerata pada rangkaian alat simulator getar.

Tabel 1. Data perhitungan amplitudo frekuensi $3.3 \mathrm{~Hz}$

\begin{tabular}{cccc}
\hline Ulangan & $\begin{array}{c}\text { Simpangan } \\
\text { terjauh }\end{array}$ & $\begin{array}{c}\text { Titik } \\
\text { setimbang }\end{array}$ & $\begin{array}{c}\text { Amplitudo } \\
\text { (cm) }\end{array}$ \\
\hline I & 16.2 & 11.4 & 4.8 \\
II & 16.1 & 11.3 & 4.8 \\
III & 16.1 & 11.3 & 4.8 \\
\hline \multicolumn{3}{c}{ Rata-rata amplitude } & 4.8 \\
\hline
\end{tabular}

Berdasarkan data diatas diketahui bahwa amplitudo ratarata pada III ulangan yakni $4,8 \mathrm{~cm}$, masuk kedalam kondisi jalan buruk (aspal), sehingga dapat ditentukan perhitungan jarak sebagai berikut:

$$
\begin{aligned}
& T=\frac{1}{f}=\frac{1}{3.3}=0.303 \frac{\text { detik }}{\text { getaran }} \\
& \omega=\frac{2 \pi}{T}=\frac{2 \pi}{0.303}=20.72 \frac{\text { getaran }}{\text { detik }}
\end{aligned}
$$

Keterangan :

$$
\begin{aligned}
& T=\text { periode getaran }\left(\frac{\text { detik }}{\text { getaran }}\right) \\
& \omega=\text { kecepatan sudut dari gerak pegas }\left(\frac{\text { getaran }}{\text { detik }}\right)
\end{aligned}
$$

Luas satu siklus getaran pada kondisi jalan luar kota yang rata:

$$
\begin{aligned}
& \text { Luas satu siklus getaran } \\
& =A \int_{0}^{T} \sin \omega T d T \\
& =4.8 \int_{0}^{0,4} \sin 20,27 T d T \\
& =4.8\left[-\frac{1}{20.27}(\cos (20.27 x 0,303)-(\cos 20.27 \times 0))\right] \\
& =4.8\left[-\frac{1}{20.27}(\cos (6.141)-(\cos 0))\right] \\
& =4.8\left[-\frac{1}{20,27}(0.994-1)\right] \\
& =1.42 \times 10^{-3} \frac{\text { cm }^{2}}{\text { getaran }}
\end{aligned}
$$

Jumlah getaran selama 1 jam

$$
=t \text { (dalam sekon) } x \text { frekuensi }
$$$$
=60 \frac{\text { menit }}{\text { jam }} \times 60 \frac{\text { detik }}{\text { menit }} \times 3.3 \frac{\text { getaran }}{\text { detik }}
$$$$
=11880 \frac{\text { getaran }}{\text { jam }}
$$

Jumlah luas seluruh getaran selama 1 jam

$$
=11880 \frac{\text { getaran }}{\text { jam }} \times 1.42 \times 10^{-3} \frac{\mathrm{cm}^{2}}{\text { getaran }}
$$




$$
=16.869 \frac{\mathrm{cm}^{2}}{j a m}
$$

sehingga, simulasi transportasi dengan truk selama 1 jam adalah sebagai berikut:

$$
\begin{aligned}
& =\frac{\text { jumlah luas seluruh getaran selama } 1 \text { jam }}{\text { jumlah luas getaran truk }} \\
& \times \text { panjang jalan } \\
& =\frac{16.869 \frac{\mathrm{cm}^{2}}{\mathrm{jam}}}{2.985 \frac{\mathrm{cm}^{2}}{0.5 \mathrm{jam}}} \times 30 \mathrm{~km}=84.7 \mathrm{~km}
\end{aligned}
$$

\section{Kesetaraan Simulasi Transportasi}

Perhitungan di atas menunjukkan keadaan transportasi yang dilakukan pada cabai dengan media meja getar dimana arah getaran yang terjadi yaitu vertikal dengan amplitudo $4.8 \mathrm{~cm}$ yang dapat mewakili kondisi jalan, frekuensi getaran pegas sebesar $3.3 \mathrm{~Hz}$, dan jarak simulasi setara panjang jalan $254.30 \mathrm{~km}$.

\section{Tahap Pengujian}

\section{Suhu}

Suhu diukur menggunakan alat termometer. Alat ini digunakan untuk mengukur cabai rawit sebelum dan sesudah dilakukan transportasi. Peletakan termometer berada di dalam kemasan yang berisi cabai rawit yaitu di tengah dan di samping. Sehingga nilai suhu didapatkan dengan membaca sekala pada termometer.

\section{Kerusakan Mekanis}

Pengamatan kerusakan mekanis dilakukan secara visual pada fisik cabai rawit segar setelah simulasi transportasi di atas meja getar. Kriteria rusak didasarkan terdapatnya luka memar, luka gores pada kulit, hingga luka pecah terhadap fisik cabai rawit segar di tiap-tiap pengemasan. Kerusakan mekanis dapat dihitung satu persatu yang rusak secara keseluruhan. Persamaan yang digunakan untuk menghitung kerusakan mekanis dapat dilihat pada persamaan (1):

$$
\begin{aligned}
& \text { Rusak }=\frac{\text { Jumlah Rusak }}{\text { Jumlah Total }} \times \text { Jumlah Total } \\
& \times \text { Jumlah Total Rusak } \times 100 \%
\end{aligned}
$$

Klasifikasi kerusakan pada buah adalah sebagai berikut (Afandi, 2013):

a. Luka Memar: terjadi akibat adanya benturan antar produk dengan dinding alat pengemasan atau tekanan sesama produk.

b. Luka Gores: terjadi akibat adanya gesekan antara produk dengan kemasan atau gesekan sesama produk.

c. Luka Pecah: terjadi akibat adanya tekanan yang terjadi dari arah vertikal maupun dari arah horizontal produk. Selain itu dapat juga diakibatkan karena guncangan selama proses pengangkutan.

\section{Uji Susut Bobot}

Susut bobot diukur dengan menggunakan timbangan gantung digital Moritz (Protable Electronic Scale) dengan kapasitas $50 \mathrm{~kg}$ dapat dilihat pada Gambar 1 . Dalam proses pengukuran bobot digunakan sebuah karung yang diisi cabai $50 \mathrm{~kg}$ yang kemudian digantungkan pada timbangan gantung. Pengukuran dilakukan pada sebelum dan sesuah simulasi. Menurut
Varanita (2016) rumus untuk perhitungan susut bobot dapat dilihat pada persamaan (2):

$P B=\frac{W_{0}-W_{a}}{W_{0}} \times 100 \%$

Keterangan :

$P B=$ Penurunan bobot

$W_{0}=$ Berat bahan pada awal simulasi $(\mathrm{kg})$

$W_{a}=$ Berat bahan setelah simulasi $(\mathrm{kg})$

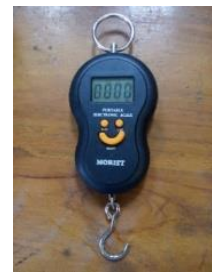

Gambar 1. Timbangan gantung digital

\section{Uji Kadar Air}

Pengukuran kadar air dilakukan dengan metode gravimetri (pengeringan menggunakan oven). Diambil sampel cabai rawit 5 gram pada bagian dan tengah dari tiap-tiap kemasan dan diletakan pada cawan aluminium yang telah diketahui berat kosongnya. Kemudian cabai tersebut dikeringkan di dalam oven dengan suhu $105^{\circ} \mathrm{C}$. Pengeringan dilakukan hingga tidak terjadi lagi penurunan berat atau sekitar 24 jam. Cabai rawit yang telah dikeringkan kemudian didinginkan di dalam desikator selama 15 menit lalu ditimbang. Setelah didapatkan data berat cawan kosong, berat awal bahan, dan berat akhir setelah pengovenan, selanjutnya kadar air dalam bahan dapat dihitung dengan persamaan (3) (Umam, 2017):

Kadar Air $=\frac{\text { Berat Awal }- \text { Berat Akhir }}{\text { Berat Awal }} \times 100 \%$

\section{Uji Kekerasan}

Tekstur buah diukur dengan menggunakan penetrometer dengan cara:

1. Ambil sampel cabai rawit segar yang sudah disimulasi sebanyak 3 sampel

2. Atur penetrometer hingga angka penetrometer mencapai 0.

3. Letakkan Sampel di bawah penetrometer, atur hingga menyentuh sampel. Kemudian tekan hingga terdengar bunyi dan dengan 3 posisi berbeda yaitu: bagian atas, bagian tengah dan bagian pangkal bawah. Diameter probe yng dipergunakan $3.5 \mathrm{~mm}$.

4. Baca angka yang tertera pada penetrometer $\left(\mathrm{kgf} / \mathrm{cm}^{2}\right)$. Kemudian catat angka yang terlihat pada penetrometer. Berikut alat penetrometer dapat dilihat pada Gambar 2.

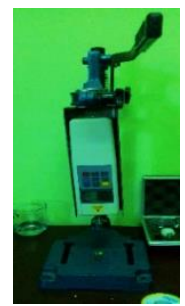

Gambar 2. Penetrometer 
Semakin keras buah maka semakin besar gaya yang dibutuhkan jarum untuk menusuk kedalam buah, sebaliknya jika buah lunak maka gaya yang diperlukan juga semakin kecil. Semakin kecil nilai tekan buah belimbing maka menunjukkan semakin rusak (Kusuma, 2010).

\section{Analisis Data}

Data yang diperoleh kemudian ditabulasi menggunakan aplikasi Microsoft Excel dan dilanjutkan dengan ANOVA (Analysis of Variance) dengan menghitung:

1. Faktor Koreksi $(F K)=\frac{\left(\sum i j Y i j\right)^{2}}{N}$

2. $J K$ Total $(J K T)=\sum X^{2}-F K$

3. $J K$ Perlakuan $(J K P)=\frac{\sum_{\text {perlakuan }}^{2}}{\text { Eulangan }}-F K$

4. $J K A=\frac{\text { Eperlakuan } 2}{r b}-F K$

5. $J K B=\frac{\text { Eperlakuan }}{2}-F K$

6. $J K A * B=J K P-J K A-J K B$

7. $J K$ Galat $(J K G)=J K T-J K P$

8. Membuat Sidik Ragam ANOVA. Apabila diperoleh hasil yang berbeda nyata, maka dilanjutkan dengan uji lanjut BNT (Beda Nyata Terkecil) pada taraf kepercayaan 5\% untuk melihat pengaruh masing-masing perlakuan dengan persamaan:

9. Notasi

$$
B N T=t_{5 \%}(\text { db galat }) x \sqrt{2 \frac{K T G}{\text { ulangan }}}
$$

\section{HASIL DAN PEMBAHASAN}

Keadaan cabai rawit segar dengan aplikasi blower dan tipe pengemasan selama digetarkan pada alat simulasi transportasi serta kerusakan cabai rawit segar setelah digetarkan pada alat simulasi transportasi dapat dibedakan dengan beberapa parameter, antara lain kerusakan mekanis, susut bobot, kadar air, dan kekerasan cabai.

Alat simulasi transportasi ini dapat bergetar secara vertikal dan diasumsikan sama dengan kondisi jalan yang berlubang-lubang, rusak, mendaki, dan menurun. Dengan demikian getaran dalam proses pengangkutan yang hanya dapat dilihat secara visual yang dapat dikuantitatifkan, sehingga dapat diperkirakan dengan besar getaran sekian jumlah kerusakan mekanis selama pengangkutan sekian pula.

Pada penelitian ini waktu 1 jam setara dengan jarak $84.76 \mathrm{~km}$ (84.76 km/jam), waktu 3 jam setara dengan $3 \times$ $484.76 \mathrm{~km}=9254.30 \mathrm{~km}$, dan RPM 198= rotasi $/$ menit setara dengan kondisi jalan saat ini dengan frekuensi 3.3 $\mathrm{Hz}$. Berikut bagian-bagian alat simulasi transportasi dapat dilihat pada Gambar 3.

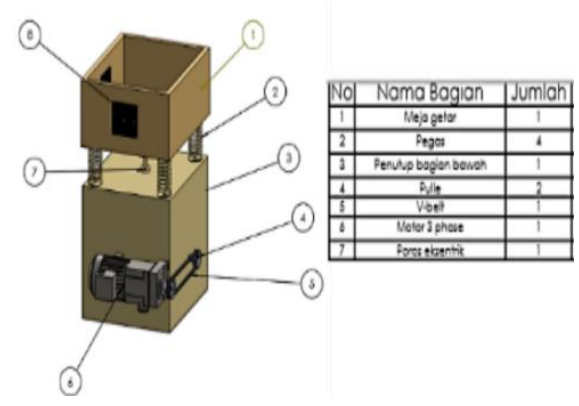

Gambar 3. Bagian-bagian alat simulasi transporasi

\section{Suhu}

Tabel 3. Hasil pengujian cabai rawit segar dengan penambahan blower dan jenis pengemasan yang ditinjau dari suhu $\left({ }^{\circ} \mathrm{C}\right)$.

\begin{tabular}{ccccc}
\hline \multirow{2}{*}{ Perlakuan } & \multicolumn{3}{c}{ Rataan Kenaikan Suhu $\left({ }^{\circ} \mathrm{C}\right)$} \\
Tengah & Samping & Pinggir \\
$\left({ }^{\circ} \mathrm{C}\right)$ & $\left({ }^{\circ} \mathrm{C}\right)$ & $\left({ }^{\circ} \mathrm{C}\right)$ \\
\hline \multirow{2}{*}{ Tanpa } & Karung & 5.6 & 5.0 & 5.0 \\
Blower & Keranjang & 5.6 & 4.3 & 5.0 \\
& Kardus & 4.0 & 3.6 & 3.6 \\
\hline \multirow{3}{*}{ Blower } & Karung & 4.0 & 3.3 & 3.0 \\
& Keranjang & 4.3 & 3.0 & 4.0 \\
& Kardus & 2.6 & 2.0 & 2.6 \\
\hline
\end{tabular}

Hasil rata-rata pengujian susut bobot terhadap cabai rawit segar dapat dilihat Tabel 3 dan Gambar 3 merupakan hasil penelitian dengan rentang suhu yaitu $2.0{ }^{\circ} \mathrm{C}-5.6^{\circ} \mathrm{C}$. Kenaikan suhu tertinggi pada penggunaan kemasaan karung sebesar $5.6{ }^{\circ} \mathrm{C}$ (tengah), $5.0{ }^{\circ} \mathrm{C}$ (samping), $5.0^{\circ} \mathrm{C}$ (pinggir) dan terendah setelah simulasi yaitu menggunakan pengemasan kardus dengan penambahan blower sebesar $2.6^{\circ} \mathrm{C}$ (tengah), $2.0^{\circ} \mathrm{C}$ (samping), $2.6^{\circ} \mathrm{C}$ (pinggir).

Namun pada grafik kenaikan suhu pinggir tertinggi pada pengemasan keranjang. Error yang terjadi ini diduga karena pada pengamatan pengambilan data suhu samping karung cepat berubah karena faktor lingkungan dan termometer yang harus bergantian untuk karung satu dengan yang lain.

Menururt Pangidoan et al. (2013), getaran selama simulasi dapat menyebabkan gesekan antar cabai dengan cabai serta cabai dengan pengemasan, sehingga cabai mengalami memar. Luka benturan atau goresan pada cabai dapat memicu proses repirasi dan transpirasi, sehingga dapat mempercepat penguapan air pada produk dan suhu dapat meningkat.

Tabel 2. Hasil pengujian cabai rawit segar dengan aplikasi blower dan tipe kemasan yang ditinjau dari kerusakan mekanis (\%), susut bobot (\%), kadar air (\%), dan kekerasan (Kgf).

\begin{tabular}{llcccc}
\hline \multirow{2}{*}{ Perlakuan } & \multicolumn{4}{c}{ Rataan \pm STD } \\
\cline { 2 - 6 } Tanpa Blower & Karung & $4.87 \pm 3.30$ & $1.58 \pm 0.50^{\mathrm{a}}$ & $0.78 \pm 0.01$ & $1.27 \pm 1.39^{\mathrm{a}}$ \\
& Keranjang & $3.87 \pm 2.86$ & $1.62 \pm 0.33^{\mathrm{a}}$ & $0.80 \pm 0.05$ & $0.72 \pm 1.76^{\mathrm{b}}$ \\
& Kardus & $1.89 \pm 0.22$ & $0.63 \pm 0.21^{\mathrm{b}}$ & $0.76 \pm 0.01$ & $1.34 \pm 1.61^{\mathrm{c}}$ \\
\hline \multirow{2}{*}{ Blower } & Karung & $4.17 \pm 0.99$ & $1.16 \pm 0.50^{\mathrm{b}}$ & $0.79 \pm 0.06$ & $1.28 \pm 1.49^{\mathrm{c}}$ \\
& Keranjang & $1.42 \pm 0.73$ & $1.33 \pm 0.59^{\mathrm{b}}$ & $0.78 \pm 0.01$ & $1.36 \pm 2.12^{\mathrm{cd}}$ \\
& Kardus & $1.27 \pm 0.13$ & $0.54 \pm 0.43^{\mathrm{b}}$ & $0.76 \pm 0.02$ & $1.57 \pm 1.95^{\mathrm{d}}$ \\
\hline
\end{tabular}

Keterangan: Notasi yang berbeda pada kolom menunjukkan adanya perbedaan yang nyata $(\mathrm{P}>0.05)$. 
Qanytah dan Ambarsari (2011) menyatakan bahwa dengan berkembangnya teknologi pengemasan, pengemasan kardus memiliki ketahanan yang baik terhadap kelembapan dan dapat didesain sesuai dengan sifat buah segar. Umumnya penggunaan pengemasan kardus karena ringan dan mudah penanganannya, juga karena dinding pengemasan relatif halus/lembut, sehingga memiliki efek penyangga, mudah didesain dalam berbagai ukuran, harganya relatif murah, dan mudah dicetak dengan desain pengemasan yang menarik.

\section{Pengaruh Aplikasi Blower dan Jenis Pengemasan Terhadap Kerusakan Mekanis}

Hasil analisis ragam menunjukkan bahwa aplikasi blower dan jenis pengemasan berbeda memberikan hasil yang tidak signifikan terhadap kerusakan cabai rawit segar $(\mathrm{P}<0.05)$ yang dibuktikan dari F.hitung $<$ F.tabel yaitu sebesar $2.14<3.11$. Perlakuan A (dengan blower, tanpa blower) memberikan hasil tidak signifikan terhadap cabai rawit segar $(\mathrm{P}<0.05)$ yang dibuktikan dari F.hitung $<$ F.tabel sebesar $3.72<3.88$. Perlakuan tipe pengemasan juga memberikan hasil tidak signifikan terhadap cabai rawit segar $(\mathrm{P}<0.05)$ yang dibuktikan dari F.hitung $<$ F.table yaitu sebesar $2.06<4.75$. Begitupula interaksi antara Perlakuan Pertama dan Kedua memberikan hasil yang tidak signifikan terhadap cabai rawit segar $(P<0.05)$ yaitu $F$. hitung < F.tabel yaitu sebesar $0.59<3.83$.

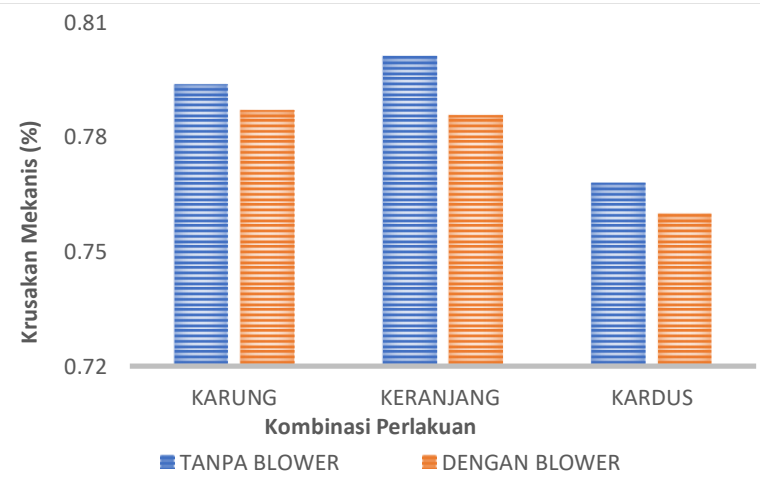

Gambar 4. Grafik kerusakan mekanis terhadap cabai rawit segar

Cabai rawit segar yang diberi blower dan jenis pengemasan kardus memberikan kehilangan kerusakan mekanis yang paling rendah pada Gambar 4. Dalam penelitian ini cabai rawit yang diberi perlakuan blower dan pengemasan kardus menunjukkan nilai paling baik dengan persentase kerusakan sebesar $1.2 \%$. Sedangkan perlakuan tanpa blower dan jenis pengemasan lainnya seperti karung dan keranjang menunjukkan persentase kerusakan yang semakin besar yaitu sebesar $4.8 \%$ dan 3.8\%. Semakin besarnya kerusakan cabai rawit segar dapat terjadi karena cabai rawit segar selama simulasi transportasi mengalami gesekan dan tekanan sehingga mudah mengalami luka memar, luka gores, atau luka pecah.

Menurut Taufik (2010), selama pengangkutan, cabai dapat mengalami kerusakan mekanis karena kontak dengan wadah atau dengan cabai yang lain akibat goncangan. Sementara menurut Fauzia et al. (2013), kerusakan mekanis pada buah dan sayuran segar paling banyak dihasilkan dari getaran dan tumbukan yang diterima oleh produk.

Kerusakan fisiologis juga bisa terjadi akibat gangguan metabolisme dalam bahan yaotu repirasi yang menghasilkan uap panas. Jika panas yang dihasilkan berlebihan akan mengakibatkan cabai menjadi layu, respirasi makin cepat, dan jaringan sel mati.

Hal ini sejalan dengan penelitian Somantri dan Syahri (2016) yang menyatakan bahwa kemasan karung yang biasa digunakan oleh petani menyebabkan kerusakan buah cabai semakin besar. Sedangkan penggunaan kemasan kardus terbukti mampu menekan kerusakan buah cabai dibanding penggunaan kemasan lainnya, dimana tingkat kerusakan buah cabai hanya $23,6 \%$, lebih rendah dibanding penggunaan karung yakni 35,9\%.

\section{Pengaruh Penambahan Blower dan Jenis Pengemasan Terhadap Susut Bobot}

Berdasarkan hasil analisis ragam, pengaruh penambahan blower dan jenis pengemasan dapat memberikan hasil yang signifikan $(P<0.05)$ terhadap susut bobot cabai rawit segar yang dibuktikan dari F.hitung > F.tabel yaitu sebesar $3.23>3.11$ maka menolak $\mathrm{H}$. Perlakuan pertama (tipe pengemasan) memberikan hasil signifikan terhadap cabai rawit segar $(\mathrm{P}<0.05)$ yang dibuktikan dari F.hitung $>$ F.tabel sebesar $7.09<3.88$. Sedangkan perlakuan B (Blower, tanpa blower) memberikan hasil tidak signifikan terhadap cabai rawit segar $(\mathrm{P}<0.05)$ yang dibuktikan dari F.hitung $<$ F.table yaitu sebesar $1.589<4.75$. Begitupula interaksi antara Perlakuan $A$ dan $B$ memberikan hasil yang tidak signifikan terhadap cabai rawit segar $(\mathrm{P}<0.05)$ yaitu $F$. hitung $<$ F.tabel yaitu sebesar $0.20<3.83$.

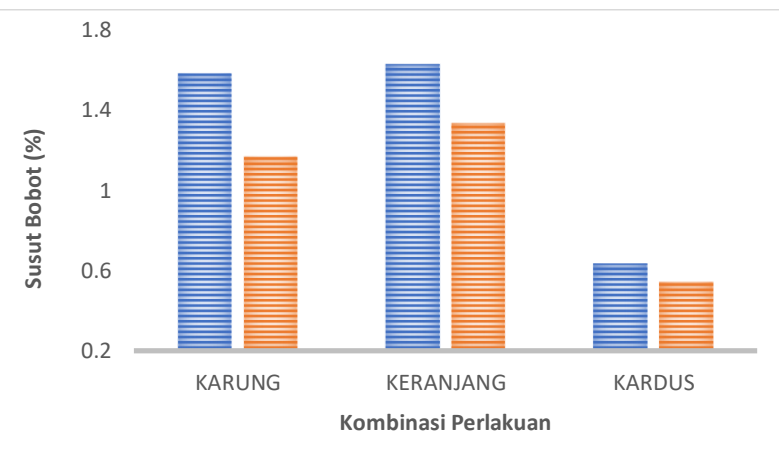

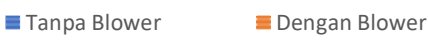

\section{Gambar 5. Grafik susut bobot terhadap cabai rawit segar}

Selanjutnya pengujian BNT (Beda Nyata Terkecil) pada tingkat kepercayaan $5 \%$ yang dapat dilihat pada Table 2 dan Gambar 5 dilakukan untuk mengetahui perbedaan tiap perlakuan yang mendominasi dalam memberikan pengaruh nyata terhadap susut bobot. Pada Tabel 2 , terlihat bahwa Perlakuan A (blower, tanpa blower) memberikan hasil pengaruh sangat nyata pada Perlakuan B (tipe pengemasan) terhadap nilai susut bobot cabai rawit segar, hal ini dapat dilihat dari notasi yang mengikutinya. Pada Tabel 2, terlihat bahwa aplikasi blower menghasilkan nilai cabai rawit segar yang rendah, artinya dengan pemberian blower maka susut bobot cabai rawit segar akan semakin rendah.

Cabai rawit segar yang diberi blower dan jenis pengemasan kardus memberikan penurunan kehilangan susut bobot yang paling rendah dapat dilihat pada Gambar 5. Dalam penelitian ini cabai rawit yang diberi perlakuan blower dan pengemasan kardus menunjukkan nilai paling baik dengan persentase kehilangan yaitu sebesar $0.54 \%$ sedangkan tanpa blower dan jenis pengemasan lainnya seperti karung dan keranjang yang penurunan beratnya sebesar $1.58 \%$ dan $1.62 \%$. Penggunaan blower dalam penelitian ini dapat mencegah cabai rawit untuk 
mengeluarkan uap panas dan pengemasan kardus dapat mencegah terjadinya gesekan dan tekanan antara bahan dengan pengemasan lainnya selama simulasi transportasi sehingga dapat menurunkan respirasi.

Hal tersebut di atas sesuai dengan penelitian Somantri dan Syahri (2016) yang menyatakan bahwa, penggunaan kemasan yang tepat seperti kemasan kardus terbukti mampu menekan kerusakan buah cabai oleh faktor-faktor tersebut, sehingga susut bobot buah cabai selama pengangkutan juga dapat dikurangi. Menurut Nurdjannah (2014), perubahan susut bobot pada cabai disebabkan oleh proses respirasi dan transpirasi yang mengakibatkan kehilangan substrat dan air, dimana ini ditandai dengan layu dan mengerutnya permukaan cabai sehingga mengurangi penerimaan konsumen dan harga jual.

\section{Pengaruh Aplikasi Blower dan Tipe Pengemasan Terhadap Kadar}

Hasil analisis ragam menunjukkan bahwa, penambahan blower dan jenis pengemasan yang berbeda memberikan pengaruh yang tidak tidak signifikan terhadap kadar cabai rawit segar $(\mathrm{P}<0.05)$ yang dibuktikan dari F.hitung $<$ F.tabel yaitu sebesar $30.57<3.11$ maka menerima HO. Perlakuan A (jenis pengemasan) memberikan hasil tidak signifikan terhadap cabai rawit segar $(\mathrm{P}<0.05)$ yang dibuktikan dari F.hitung < F.tabel sebesar $1.23<3.88$. Perlakuan B (Blower, tanpa blower) juga memberikan hasil tidak signifikan terhadap cabai rawit segar $(\mathrm{P}<0.05)$ yang dibuktikan dari F.hitung < F.table yaitu sebesar $0.10<4.75$. Begitupula interaksi antara Perlakuan A dan B memberikan hasil yang tidak signifikan terhadap cabai rawit segar $(\mathrm{P}<0.05)$ yaitu $\mathrm{F}$. hitung $<$ F.tabel yaitu sebesar $0.15<3.83$.

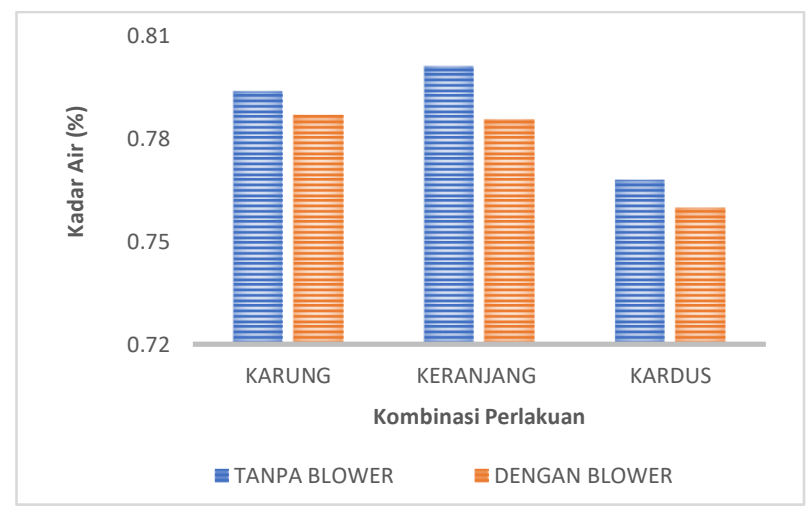

\section{Gambar 6. Grafik kadar air terhadap cabai rawit segar}

Cabai rawit segar dengan perlakuan penambahan blower dan jenis pengemasan berbeda menunjukkan terjadinya peningkatan kadar air terhadap cabai rawit segar selama transportasi pada Gambar 6. Peningkatan nilai kadar air yang bervariasi ini dapat dilihat dari kandungan air pada cabai rawit (kontrol) $67.86 \%$ sedangkan kadar air cabai rawit setelah simulasi transportasi berkisar 76\%-80\%. Dalam penelitian ini, penggunaan blower dan pengemasan kardus merupakan perlakuan yang sangat tepat selama proses transportasi. Hal ini dapat diketahui dari nilai kadar air cabai rawit pada perlakuan tersebut $76 \%$ sedangkan pada perlakuan tanpa blower dan pengemasan keranjang memiliki nilai kadar air tertinggi sebesar $80 \%$.

Meningkatnya kadar air cabai rawit diduga akibat suhu bahan di dalam pengemasan dengan suhu lingkungan memiliki tekanan yang berbeda, sehingga bahan mengalami kenaikan kadar air. Mekanisme blower selama transportasi dapat merubah suhu yang ada di lingkungan seiring masuk ke dalam bahan akan menghasilkan uap panas dengan jumlah sedikit sehingga kadar air cabai rawit pada penggunaan blower lebih baik dibandingkan kadar air tanpa blower.

Menurut Utama et al (2002), tekanan uap air bergerak dari konsentrasi tinggi ke konsentrasi rendah. Kadar air merupakan titik kritis umur simpan dianggap sensitif serta dapat menimbulkan terjadinya perubahan mutu produk selama distribusi, penyimpanan hingga siap dikonsumsi. Menurut Herawati (2008), faktor yang sangat berpengaruh terhadap penurunan mutu produk pangan adalah perubahan kadar air dalam produk. Perubahan kadar air bahan dapat dipengaruhi oleh suhu dan kelembaban ruangan selama penyimpanan.

\section{Pengaruh Aplikasi Blower dan Jenis Pengemasan Terhadap Kekerasan Cabai Rawit}

Hasil analisis ragam menunjukkan bahwa, penambahan blower dan jenis pengemasan berbeda memberikan hasil yang signifikan terhadap kekerasan cabai rawit segar $(\mathrm{P}>0.05)$ yang dibuktikan dari F.hitung > F.tabel yaitu sebesar $3.82>3.11$ maka menerima H0. Perlakuan pertama (jenis pengemasan) memberikan hasil signifikan terhadap cabai rawit segar $(P>0.05)$ yang dibuktikan dari F.hitung > F.tabel sebesar $4.07>3.88$. Perlakuan kedua (Blower, tanpa blower) juga memberikan hasil signifikan terhadap cabai rawit segar $(P>0.05)$ yang dibuktikan dari F.hitung > F.table yaitu sebesar $6.05>4.75$. Begitupula interaksi antara faktor A dan B memberikan hasil yang tidak signifikan terhadap cabai rawit segar $(P<0.05)$ yaitu $F$. hitung $<$ F.tabel yaitu sebesar $2.44<3.83$.

Selanjutnya dilakukan pengujian BNT (Beda Nyata Terkecil) pada tingkat kepercayaan $5 \%$ yang dapat dilihat pada Table 2 dan Gambar 7 untuk mengetahui perbedaan tiap perlakuan yang mendominasi dalam memberikan pengaruh nyata terhadap kekerasan cabai rawit segar. Hasilnya dapat dilihat pada Tabel 2. Dari hasil tersebut dapat dilihat bahwa faktor pertama (blower, tanpa blower) dan memberikan hasil yang signifikan pada faktor kedua (jenis pengemasan) terhadap nilai kekerasan cabai rawit segar, hal ini dapat dilihat dari notasi yang mengikutinya. Pada Tabel tersebut menunjukkan bahwa pemberian blower menghasilkan nilai cabai rawit segar yang tinggi, artinya dengan pemberian blower maka kekerasan cabai rawit segar akan semakin tinggi.

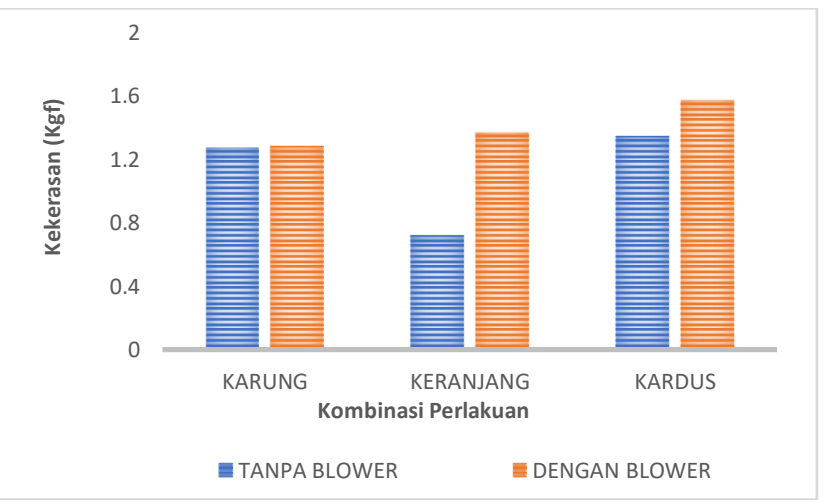

Gambar 7. Grafik kekerasan terhadap cabai rawit segar

Penggunaan blower menunjukkan lebih bagus untuk tekstur/kekerasan cabai rawit segar dapat dilihat pada Gambar 7. Dalam penelitian ini cabai rawit yang diberi perlakuan blower dan pengemasan kardus menunjukkan nilai kekerasan cabai rawit yang paling baik sebesar 1.574 $\mathrm{kgf} / \mathrm{cm}^{2}$ sedangkan nilai kekerasan paling rendah sebesar $0.721 \mathrm{kgf} / \mathrm{cm}^{2}$ pada perlakuan tanpa blower dan 
pengemasan. Tinggi dan rendahnya nilai kekerasan terjadi karena cabai rawit segar selama simulasi transportasi mengalami guncangan selama 3 jam. Akibat guncangan tersebut, cabai mengalami gesekan dan tekanan terhadap bahan dengan bahan serta bahan dengan kemasan sehingga dapat merubah nilai kekerasan pada cabai rawit segar.

Menurut Zhou et al. (2016) mengatakan bahwa, frekuensi getaran yang lebih rendah menghasilkan tingkat kerusakan yang lebih rendah, sebaliknya. Menururt Pujimulyani (2009) menjelaskan bahwa, tekstur pada produk hortikultura yang bervariasi dipengaruhi oleh ketebalan kulit luar, kandungan total zat padat dan juga pati. Faktor internal lain yang mempengaruhi tekstur produk hortikultura yaitu adanya kandungan pektin pada dinding sel. Pektin berbentuk propektin yang tidk larut dalam air terhadap jaringan yang masih muda. Selama proses pematangan, propektin berubah menjadi pektin yang larut dalam air. Akibat dari perubahan ini, tekstur buah cabai menjadi lunak.

Penggunaan blower diduga dapat mengurangi uap panas yang dihasilkan cabai rawit selama simulasi transportasi dan penggunaan pengemasan kardus dapat melindungi bahan karena permukaannya yang lebih halus serta terdapat pipa ditengah kemasan sebagai jalur keluar masuknya hembusan blower melalui sisi kanan dan kiri kemasan (ventilasi), sehingga nilai kekerasan terhadap cabai rawit pada perlakuan blower dan pengemasan kardus lebih tinggi dibandingkan perlakuan lainnya.

Menurut Fadiji et al. (2016) mengatakan bahwa, pengemasan kardus berventilasi yang digunakan secara luas dalam industri buah dirancang untuk meminimalkan penanganan kerusakan dan memfasilitasi aliran udara di sekitar produk untuk mempertahankan rantai dingin. Sedangkan penelitian yang sudah dilakukan Paternoster et al. (2017), kombinasi pengemasan kardus dengan foil plastik terhadap botol minuman bir menjadikan strategi pengemasan terbaik mengenai peredaman getaran dan insulasi termal, karena kardus memiliki sifat insulasi termal positiff. Foil plastik mengikat botol bir bersama-sama menyisakan sedikit ruang untuk botol bergerak dan untuk itu mengurangi transfer udara yang berkontribusi terhadap sifat insulasi panas yang lebih baik.

\section{KESIMPULAN}

Hasil penelitian ini dapat disimpulkan bahwa aplikasi blower pada proses transportasi dapat meningkatkan mutu cabai rawit karena panas yang dikeluarkan bahan dapat dicegah, selain itu jenis pengemasan kardus menunjukkan mampu memberi perlindungan yang lebih aman selama proses transportasi. Sehingga didapatkan nilai parameter kerusakan mekanis sebesar $1.42 \%$, susut bobot sebesar $0.54 \%$, kadar air sebesar $0.76 \%$, dan kekerasan sebesar $1.57 \mathrm{Kgf} / \mathrm{cm}^{2}$. Aplikasi blower dan tipe pengemasan berpengaruh nyata terhadap penurunan susut bobot dan kekerasan cabai rawit segar, serta nilai tidak berpengaruh nyata terhadap kerusakan mekanis dan penurunan kadar air.

\section{DAFTAR PUSTAKA}

Afandi MIR. (2013). Pengaruh Bahan Pengisi Kemasan Terhadap Kerusakan Mekanis Pada Buah Markisa Kuning (Passiflora flavicarpa) Selama Transportasi. Skripsi. Fakultas Sarjana, IPB. Bogor
Fadiji T, Coetzee C, Chen L, and Chukwu O. (2016). Susceptibility of apples to bruising inside ventilated corrugated paperboard packages during simulated transport damage. J. Postharvest Biology and Technology 118(2016):111-119

Fauzia K, Lutfi M, Hawa LC. (2013). Penentuan tingkat kerusakan buah alpukat pada posisi pengangkutan dengan simulasi getaran yang berbeda. J. Keteknikan Pertanian Tropis dan Biosistem 1(1): 50-54.

Herawati, Heny. (2008). Penentuan umur simpan pada produk pangan. J. Litbang Pertanian 27(4): 124-130

Kusuma BN. 2010. Pengaruh Perlakuan Pengemasan Belimbing (Averrhoa carambola $L$ ) dengan Penggunaan Bahan Pengisi Terhadap Mutu Fisik Belimbing Selama Transportasi. Departemen Teknik Pertanian. IPB. Bogor

Nurdjannah, R. (2014). Perubahan Kualitas Cabe Merah Dalam Berbagai Jenis Kemasan Selama Penyimpanan Dingin (Tesis). Program Pascasarjana. IPB. Bogor

Pangidoan S. (2013). Simulasi transportasi dengan pengemasan untuk cabai merah keriting segar. $J$. Keteknikan Pertanian 27(1):69-76

Paternoster A, Camp JV, Vanlanduit S, and Weeren A. (2017). The performance of beer packaging: Vibration damping and thermal insulation. J. Food Packaging and Shelf Life 11 (2017) 91-97

Qanytah dan Ambarsari I. (2011). Efisiensi penggunaan kemasan kardus distribusi mangga arumanis. $J$. Litbang Pertanian 30(1): 8-15

Raharjo, Parno. (2016). Karakteristik getaran pada backward inclined blade bloer karena perubahan kecepatan. J. Teknik Mesin 11(03)

Sembiring N. (2009). Pengaruh Jenis Bahan Pengemas Terhadap Kualitas Produk Cabai Merah (Capsium annum L) Segar Kemasan Selama Penyimpanan Dingin. Tesis. Sekolah Pascasarjana Universitas Sumatra Utara. Medan.

Somantri RU dan Syahri. (2016). Kajian pengaruh berbagai jenis kemasan terhadap kehilangan hasil cabai selama pengangkutan. J. Prosiding Seminar Nasional Lahan Subotimal 576-583

Taufik, M. (2010). Analisis pendapatan usahatani dan penanganan pasca panen cabai merah. J. Litbang Pertanian 30(2): 66-72

Umam K. (2017). Respon Kualitas Cabai Rawit Merah (Capsicum Frutescens L.) terhadap Suhu Penyimpanan. Departemen Teknik Mesin dan Sistem. IPB. Bogor

Varanita ZA. (2016). Pengaruh Getaran Terhadap Kerusakan Mekanis Buah Tomat (Lycopersicum Esculentum Mill). Sarjana Teknologi Pertanian. Universitas Lampung. Lampung

Zhou J, He L, Karkee M, and Zhang Q. (2016). Analysis of shaking-induced cherry fruit motion and damage. J. Biosystem Engineering 144:105-114. 